\title{
AFTER THE PARIS AGREEMENT: HOW INDIA CAN USE CLIMATE FINANCING TO IMPLEMENT A SUSTAINABLE CLEAN COOKSTOVE PROGRAM
}

\author{
A Thesis \\ presented to \\ the Faculty of California Polytechnic State University, \\ San Luis Obispo
}

In Partial Fulfillment

of the Requirements for the Degree

Master of City and Regional Planning

by

Hannah Rose Kornfeld

June 2016 
(C) 2016

Hannah Rose Kornfeld

ALL RIGHTS RESERVED 
TITLE: $\quad$ After the Paris Agreement: How India Can Use Climate Financing to Implement a Sustainable Clean Cookstove Program

AUTHOR: Hannah Rose Kornfeld

DATE SUBMITTED: June 2016

COMMITTEE CHAIR: William W. Riggs, Ph.D., AICP, LEED AP Assistant Professor of City and Regional Planning California Polytechnic State University, San Luis Obispo

COMMITTEE MEMBER: David I. Levine, Ph.D.

Trefethen Professor of Business Administration University of California, Berkeley

COMMITTEE MEMBER: Adrienne I. Greve, Ph.D. Associate Professor of City and Regional Planning California Polytechnic State University, San Luis Obispo 


\section{ABSTRACT \\ After the Paris Agreement: How India Can Use Climate Financing to Implement a Sustainable Clean Cookstove Program \\ Hannah Rose Kornfeld}

The burning of biomass for cooking purposes without proper ventilation and filters poses a massive health and climate risk. Health implications from exposure to household air pollution from this type of fuel impacts women and children in many developing countries, who spend many hours a day cooking and gathering fuel. Climate implications from burning solid biomass results in increased carbon dioxide and black carbon emissions, which contribute to global climate change. This thesis aims to explore the issues associated with biomass cookstoves in terms of both health and climate, and seeks to understand how a new national clean cookstove program could be funded in India. This includes potential partnerships with United States agencies, nonprofit organizations, and other international funding sources. The topic of clean cookstoves has gained traction as a strategy to mitigate emissions and adapt to a changing climate, and with the recent passing of the United Nations Paris Agreement, funding is increasing to support programs that address climate impacts.

Keywords: Clean cookstoves, Paris Agreement, COP 21, climate finance, India 


\section{ACKNOWLEDGMENTS}

I would like to express my gratitude to my committee chair, Dr. William Riggs, as well as my committee members, Dr. David Levine and Dr. Adrienne Greve. Their comments and insight during this process were invaluable. I would also like to thank my classmate, Jana Schwartz, for undergoing this process with me, as well as my parents, Jeannie and Amos Kornfeld, who provided the emotional support I needed. 


\section{TABLE OF CONTENTS}

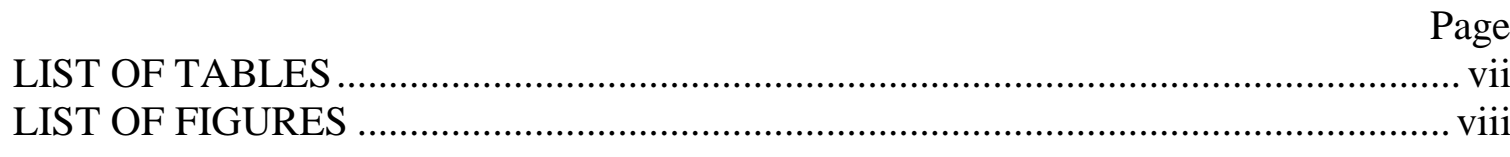

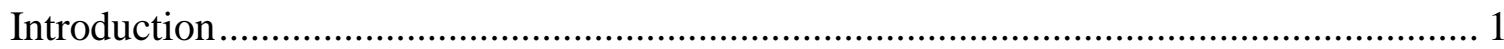

What is a Cookstove? Why Clean Cookstoves? ...................................................... 1

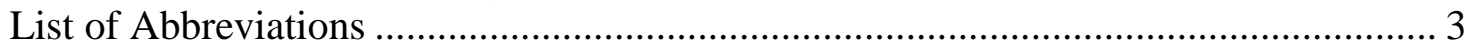

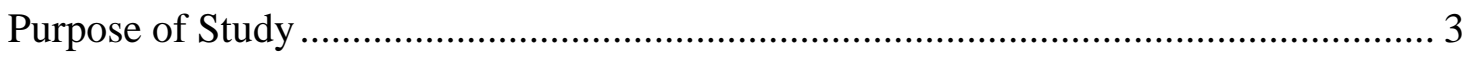

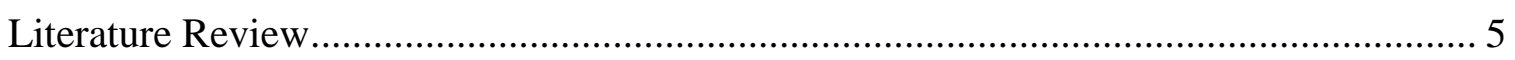

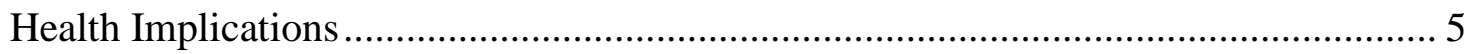

Household Air Pollution ................................................................................ 5

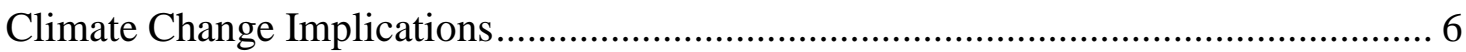

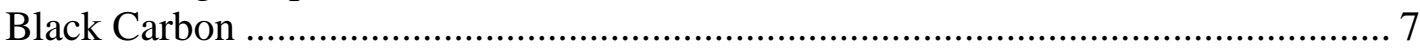

Forest and Land Implications........................................................................... 8

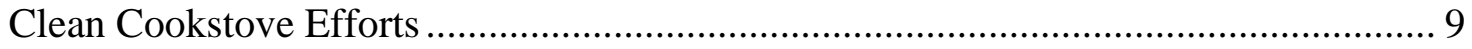

History of Cookstove Programs ........................................................................ 9

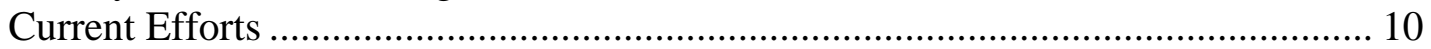

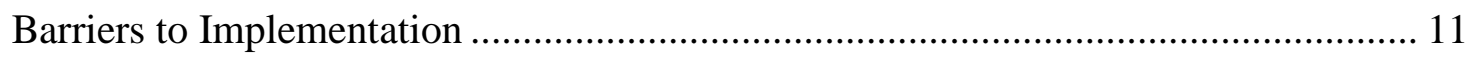

Needs Assessment for a Sustainable Clean Cookstove Program in India ........................ 13

History of National Cookstove Programs ………................................................ 13

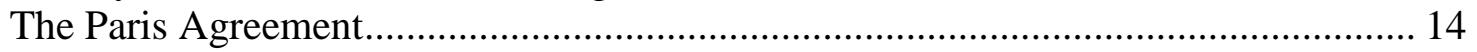

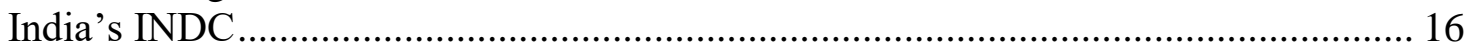

The Need for a Sustainable Clean Cookstove Program ............................................ 18

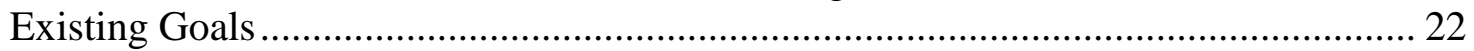

A New National Program................................................................................... 23

Funding a New National Program with U.S. Assistance ……………………………..... 25

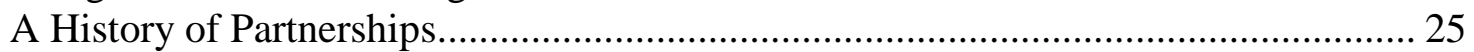

India's Financial Contribution to Clean Cookstoves ...................................................... 25

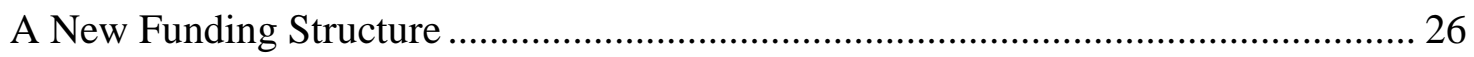

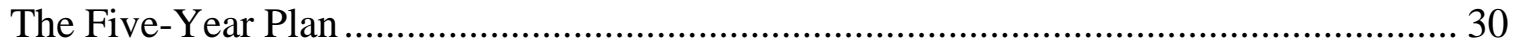

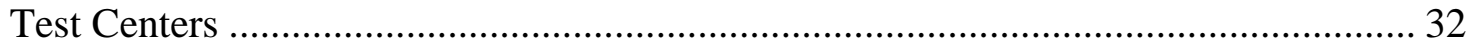

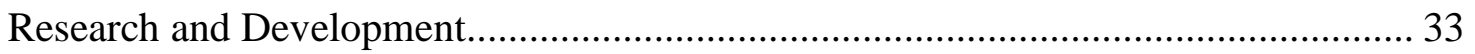

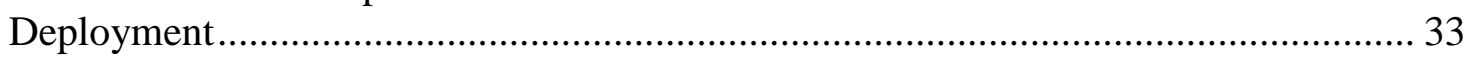

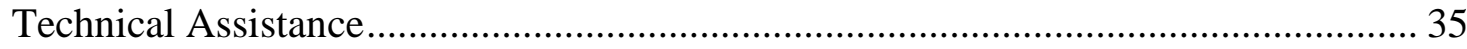

Monitoring and Evaluation ............................................................................ 35

Education and Outreach Activities ………………................................................. 35

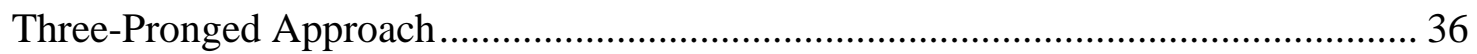

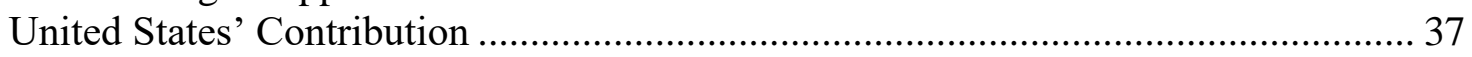

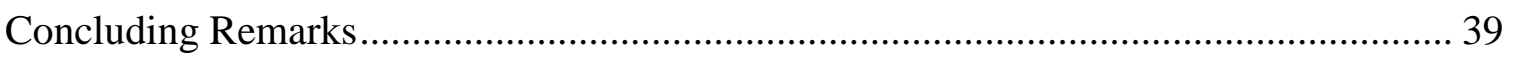

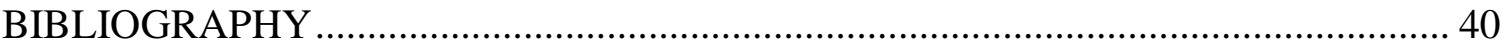




\section{LIST OF TABLES}

Table

Page

Table 1. DALYs in South Asia by Risk Factor, 2010. Modified from (Smith, 2013)....... 6

Table 2. Overview of benefits and costs of clean cookstoves. Modified from (Malla \&

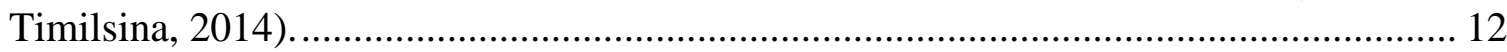

Table 3. United States Climate Finance Contributions in 2012. Modified from

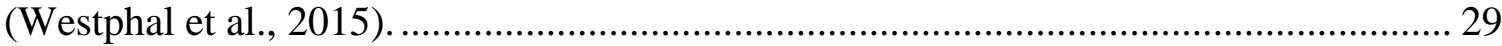

Table 4. Five-Year Budget for New National Program................................................ 32

Table 5. Suggested Funding Allocation by Organization for New National Program. .... 38 
Figure

\section{LIST OF FIGURES}

Page

Figure 1. Total GHG Emissions Including Land Use Change and Forestry $\left(\mathrm{MtCO}_{2} \mathrm{e}\right)$

India vs. United States. Data from database: CAIT Climate Data Explorer, 2015.

Figure 2. Total Wood Removed for Wood Fuel Purposes from Indian Forests,

1990-2011. Source: Global Forest Resources Assessments, Food and Agriculture

Organization of the United Nations.

Figure 3. History of Paris Agreement. Modified from "Background on the UNFCCC:

The International Response to Climate Change."

Figure 4. Energy Production by Source in India, 1990-2013. Data from database:

World Development Indicators, 2016.

Figure 5. Mortality Rate of Children Under 5 (per 1,000) India vs. World. Data from database: World Development Indicators, 2016.

Figure 6. Number of Households by Type of Fuel Used for Cooking. Source: Census

of India 2011.

Figure 7. Rural versus Urban Population Projection in India. Source: Health Nutrition and Population Statistics: Population estimates and projections. Retrieved from World DataBank, 2016.

Figure 8. Funding Flowchart for New National Program with U.S. Assistance.

Figure 9. USAID Support Programs to India. Source: 2016 Congressional Budget

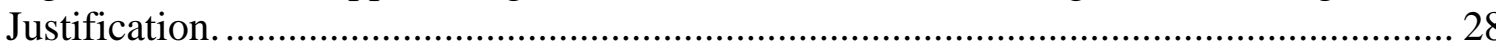

Figure 10. Budget for UCA Programme by Percentage. ........................................... 32

Figure 11. Strategy to Strengthen Clean Cookstove Market in India. Modified from (Global Alliance for Clean Cookstoves, 2012)..... 


\section{Introduction}

This thesis aims to understand if developing countries such as India can use the funding allocated through the recent COP 21 Climate Agreement to implement clean cookstove programs. Cookstoves in many countries rely on biomass for fuel, lack proper filters and ventilation, and have led to a health crisis among infants and women who spend a vast amount of time around the stoves. There are also climate implications for using cookstoves that burn biomass fuels, such as deforestation, black carbon emissions, and glacial melting. By providing the funding necessary to implement clean cookstove programs, countries can begin to tackle these health and climate concerns, bettering their society, economy, and environment.

This thesis includes a literature review of the health and climate issues associated with cookstoves, existing efforts to initiate clean cookstove programs, as well as an overview of the COP 21 agreement, as it pertains to funding opportunities. The paper then delves into the possibility of partnerships between the United States and India to begin the sustained funding of a new national clean cookstove program.

\section{What is a Cookstove? Why Clean Cookstoves?}

A cookstove is a locally produced stove made from available and low-cost materials such as stones, ceramics, clay, and bricks (Global Alliance for Clean Cookstoves, 2016c). Traditional cookstoves often do not include filters or ventilation to protect those around the stove from inhaling the smoke. Improving cookstoves is essential not only from a health standpoint, but also an environmental one. According to Lewis et al., almost half the world currently relies on solid biomass fuel for cooking purposes (2015), and in some countries, such as India, the percentage of those cooking with solid biomass can exceed $70 \%$. This 
solid biomass can come in the form of wood, animal dung, and charcoal (Ruiz-Mercado, Masera, Zamora, \& Smith, 2011). It is estimated that approximately 2.4 billion people worldwide currently depend on burning these types of solid biomasses for cooking purposes (Ruiz-Mercado et al., 2011).

Clean cookstoves, for this analysis, are stoves that improve energy efficiency, reduce indoor pollution, and increase ease of use and are often disseminated by governments, NGOs, and other organizations (Barnes, Kumar, \& Openshaw, 2012). These types of stoves use modern technology to decrease fuel use and cost, decrease cooking time, emit less smoke and improve air quality, which can potentially improve the health of both children and cooks, which are often women (Lewis et al., 2015). Rather than using traditional biomass to run, clean cookstoves can run on liquefied petroleum gas (LPG), or electricity (Lewis et al., 2015). While these improved types of stoves have been available in many developing countries, the challenge has been in the deployment of the technology and the availability of the power source, as electricity supply and LPG fuels are often not dependable in developing countries and can be prohibitively expensive (Lewis et al., 2015). 


\section{$\underline{\text { List of Abbreviations }}$}

$\begin{array}{ll}\text { Alliance } & \text { Global Alliance for Clean Cookstoves } \\ \text { COP 21 } & 21^{\text {st }} \text { Conference of the Parties in Paris } \\ \text { DALY } & \text { Disability-adjusted life years } \\ \text { DOE } & \text { Department of Energy (U.S.) } \\ \text { GHG } & \text { Greenhouse gas } \\ \text { HAP } & \text { Household air pollution } \\ \text { IEA } & \text { International Energy Agency } \\ \text { INDC } & \text { Intended Nationally Determined Contributions } \\ \text { LPG } & \text { Liquefied petroleum gas } \\ \text { MNRE } & \text { Ministry of New and Renewable Energy (India) } \\ \text { NAPCC } & \text { National Action Plan for Climate Change (India) } \\ \text { NBCI } & \text { National Biomass Cookstove Initiative (India) } \\ \text { OAP } & \text { Outdoor air pollution } \\ \text { OPIC } & \text { Overseas Private Investment Corporation } \\ \text { PACE } & \text { Partnership to Advance Clean Energy (U.S.-India) } \\ \text { UCA } & \text { Unnat Chulha Abhiyan Program (India) } \\ \text { UNFCCC } & \text { United Nations Framework Convention on Climate Change } \\ \text { USAID } & \text { U.S. Agency for International Development } \\ \text { WHO } & \text { World Health Organization }\end{array}$

$\underline{\text { Purpose of Study }}$

With the recent signing of the Paris Agreement, there is a sense of hope for climate action, accompanied with a concern for how implementation of the Agreement will be carried out. While there is speculation from nonprofit and nongovernmental organizations and the media, it is unclear how the articles of the Agreement will be enforced or unfold. One of the unique aspects of this agreement is the climate financing that will be available to developing countries for both climate mitigation and adaptation purposes. Since this funding has not yet been allocated, and likely won't be until 2020 when the developed countries' funds are due, there are many possible initiatives that could qualify as climate actions.

Due to the many climate implications associated with cookstoves and the fact that many of those subject to using the stoves are some of the world's most vulnerable and poor, 
this financing brings optimism that a large-scale clean cookstove initiative would be possible. This study seeks to understand the need for a new national clean cookstove program in India, looking at climate and health data, as well as how India could partner with the United States to fund a program through its federal governmental ministries with support from NGOs and other organizations. 


\section{Literature Review}

\section{Health Implications}

Health implications from the use of cookstoves include child pneumonia, chronic obstructive pulmonary disease, lung cancer, low child cognitive function, low birth weight, cervical cancer, adverse pregnancy outcomes, asthma, and tuberculosis. The International Energy Agency (IEA) estimates that by 2030 there will be more premature deaths associated with burning biomass indoors than deaths from HIV/AIDS (Malla \& Timilsina, 2014).

Women are often the family members responsible for fuel collection, a process that can require 5-8 hours per week. The health implications of carrying heavy loads of fuel can result in head and spinal injuries, pregnancy complications, and maternal mortality (Global Alliance for Clean Cookstoves, 2013). The use of the stove can also result in burns from the open fires. More than 500,000 women suffer moderate to severe burns each year, mostly due to unsafe cookstoves. This issue is further exacerbated by the lack of access to doctors and medical facilities (Global Alliance for Clean Cookstoves, 2013).

\section{Household Air Pollution}

Burning solid biomass fuels can release toxic substances into the air. This includes carbon monoxide, particulates, benzene, and formaldehyde (Global Alliance for Clean Cookstoves, 2013). These pollutants can cause acute lower respiratory infections, chronic obstructive pulmonary diseases, lung cancer, cataracts, and other health implications. Cooking is often done in poorly ventilated areas, as well as in cramped conditions such as the corner of a room, allowing the entire house to fill with smoke and affecting all people inside (Global Alliance for Clean Cookstoves, 2013). Estimates from the World Health 
Organization (WHO) suggest that about 8 million babies are prone to health conditions from exposure to household air pollution (HAP) (Global Alliance for Clean Cookstoves, 2013). The majority of women keep their children nearby while they are cooking. Most of the children are under five years old, thus WHO suggested an additional 40 million children are indirectly affected by HAP from cookstoves (Global Alliance for Clean Cookstoves, 2013).

Disability-adjusted life years (DALYs) are a measure to "compare death and disability... by combining years of life lost from premature death and years of healthy life lost by being in a state of poor health or disability" (Preedy \& Watson, 2010, p. 4184). As demonstrated in Table 1, HAP is the greatest risk to DALYs in South Asia. In India specifically, HAP is responsible for 875,000 deaths each year, with about 16.9 million DALYs lost due to the use of solid biomass fuels (Global Alliance for Clean Cookstoves, 2013). HAP is not only an indoor air pollution concern, as it contributes about $16 \%$ to outdoor air pollution (OAP) globally (Smith, 2013).

Table 1. DALYs in South Asia by Risk Factor, 2010. Modified from (Smith, 2013).

\begin{tabular}{l}
\hline DALYs in South Asia by Risk Factor, 2010 \\
\hline 1. Household air pollution \\
2. Smoking \\
3. High blood pressure \\
4. Childhood underweight \\
5. Low fruit \\
6. Ambient particulate matter pollution \\
\hline
\end{tabular}

\section{Climate Change Implications}

For many developing countries that are reliant on high greenhouse gas (GHG) emitting energy sources such as coal, the introduction of clean cookstoves could have dramatic impacts on lowering emissions. For example, if India implemented all clean 
cookstoves, the country's total GHG emissions would decrease by four percent (Malla \& Timilsina, 2014). Figure 1 compares India's total greenhouse gas emissions since 1990 with the United States. India has become the third largest GHG emitter by country, while the U.S. remains second. However, as India continues to develop, its GHG emissions have steadily risen, now accounting for over four percent of the world's total emissions (Ge, Friedrich, \& Damassa, 2014).

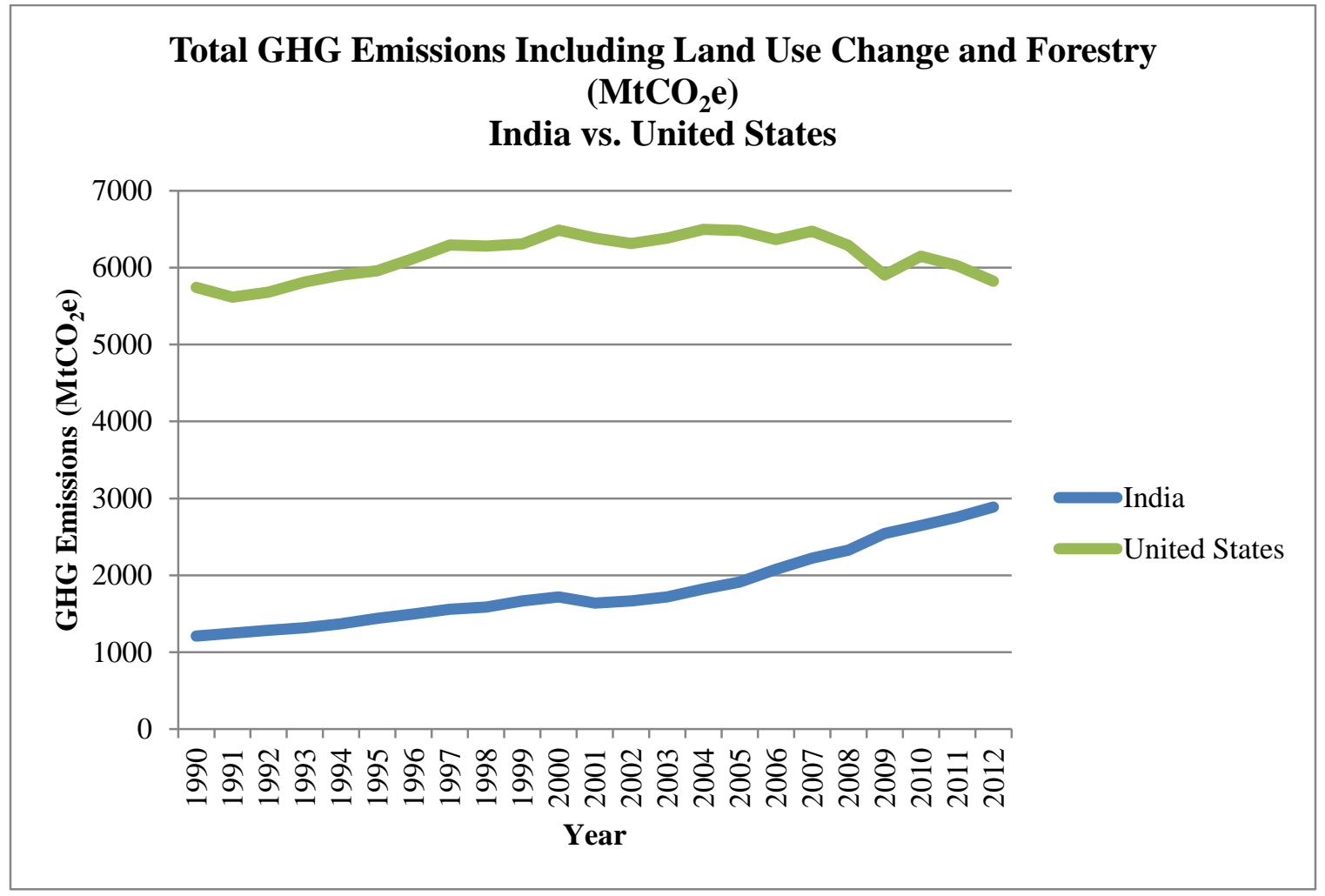

Figure 1. Total GHG Emissions Including Land Use Change and Forestry $\left(\mathrm{MtCO}_{2} \mathrm{e}\right)$ India vs. United States. Data from database: CAIT Climate Data Explorer, 2015

\section{Black Carbon}

Black carbon forms as a result of burning solid biomass fuels for cooking and heating. It is considered a short-lived greenhouse gas emitter because it only lasts in the atmosphere for several days or weeks (Sloss, 2012). By targeting a reduction in black carbon emissions, overall atmospheric effects would occur quicker than mitigating $\mathrm{CO}_{2}$ 
emissions (Sloss, 2012). Currently, China and India are the world's largest emitters of black carbon, mostly due to the fact that both countries are experiencing tremendous and unprecedented growth. Sloss (2012) identified the extent of implications from black carbon, which includes:

- Negative effects from radiative forcing;

- Indirect positive effects from radiative forcing as a result of changes in the albedo of both snow and ice;

- Positive or negative effects from semi-direct effects on clouds and precipitation;

- Negative effects on respiratory health;

- Negative effects on crop production;

- Negative effects on soil, lessening carbon sink capacity.

In India, 71\% of the black carbon emitted comes from biomass combustion (Sloss, 2012). Since much of the biomass combustion is due to cooking and heating in residential units, it is identified as the area targeted for reductions. Implementing a national level clean cookstove initiative is a step in the right direction to curb black carbon emissions.

\section{Forest and Land Implications}

Much of the biomass fuel used for cookstoves comes from wood harvested from forests. This type of wood removal can be unsustainable if serving a large population, and can lead to local forest degradation and accelerated deforestation (Brooks et al., 2015). As depicted in Figure 2, the amount of wood removed from forests in India to serve the purpose of fuel has steadily increased over the past decade, especially as the population of the country has dramatically increased.

Deforestation and forest fragmentation contribute to climate change by eliminating tree cover, exposing soil, and releasing carbon dioxide. These changes can increase surface temperatures, in a country that already witnesses high heat, as well as increase surface 
runoff, resulting in an increase in flash floods (Ali, Riaz, \& Iqbal, 2014). By adopting cookstoves that use less biomass, the risk of deforestation and forest fragmentation decreases. Maintaining forest ecosystems is often viewed as a climate adaptation initiative, and can result in another means of climate funding and financing, which will be discussed later.

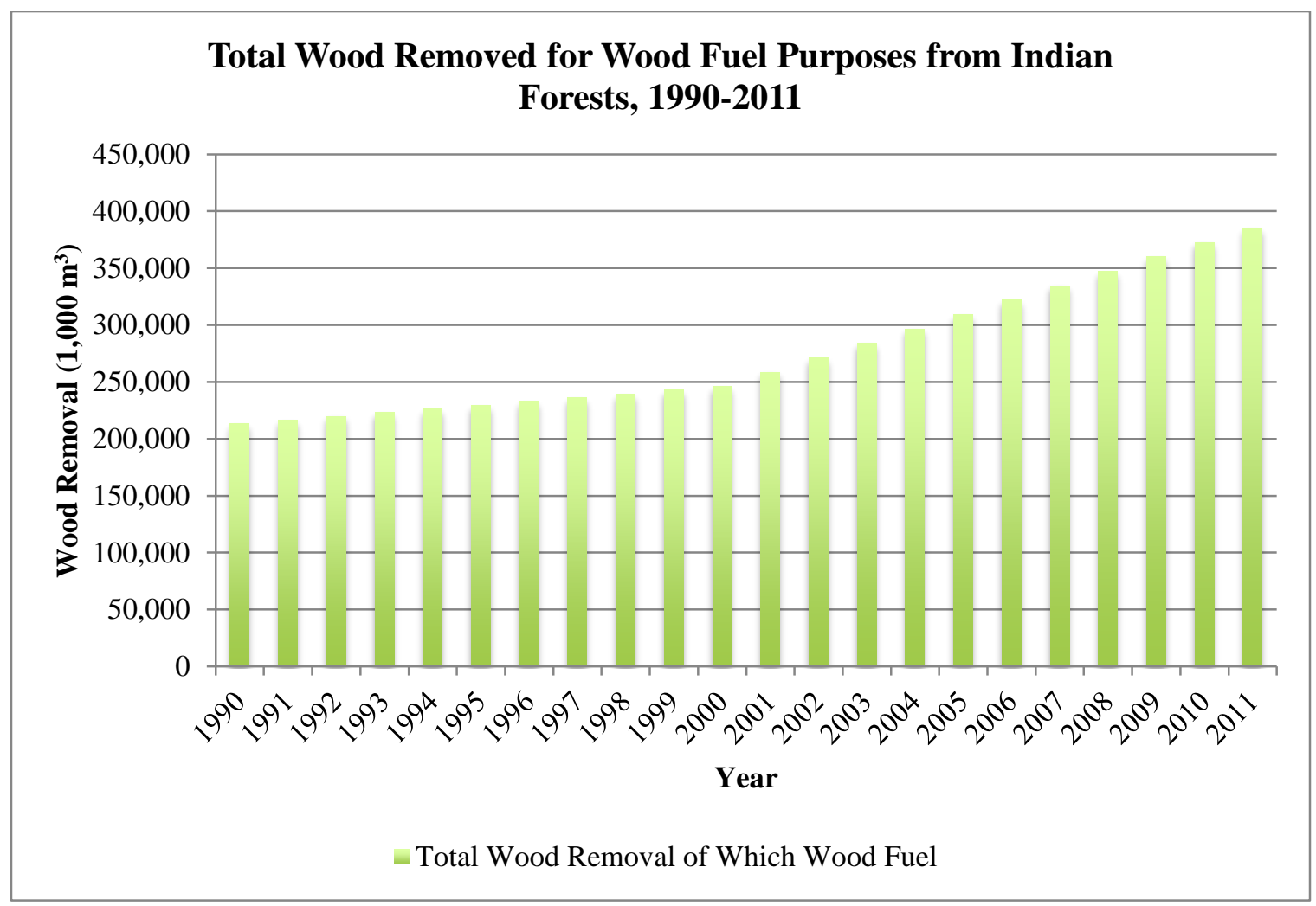

Figure 2. Total Wood Removed for Wood Fuel Purposes from Indian Forests, 1990-2011. Source: Global Forest Resources Assessments, Food and Agriculture Organization of the United Nations.

\section{Clean Cookstove Efforts}

History of Cookstove Programs

There are currently more than 160 cookstove programs active worldwide, ranging in size, scope, type of stove, technological design, dissemination, and financial mechanisms (Ruiz-Mercado et al., 2011). 
Cookstove intervention programs have been on the rise over the past few decades, as health concerns resulting from the use of stoves has increased and environmental degradation has not slowed. Some of the first clean cookstove programs began in the 1980s, with national programs in both India and China (Adler, 2010). China's program has often been considered the most successful; as over 150 million clean cookstoves have been deployed and are currently in use (Adler, 2010).

Although there has been some success with pilot and intervention programs, there is a need to do much more. In order to change the way people cook and the technology with which they cook, a variety of characteristics must be taken into consideration. It has been estimated that 600 to 800 million homes worldwide need clean cookstoves, suggesting the urgent need for successful intervention programs on a large scale (Adler, 2010).

\section{Current Efforts}

There are many current efforts globally to support clean cookstove programs. One of the more well-known and largest programs is the Global Alliance for Clean Cookstoves (Alliance), a public-private partnership that is hosted by the UN Foundation. The Alliance features eight focus countries spanning three continents (India being one of them), each with unique goals to increase the number of clean cookstoves and decrease the amount of biomass burned (Global Alliance for Clean Cookstoves, 2016b). Other large-scale clean cookstove programs include the World Bank’s African Clean Cooking Energy Solutions, the Clean Stove Initiative in East Asia and the Pacific, and the U.S. Agency of International Development's Sustainable Cookstove Sector Program. India in particular has attempted several programs, which will be discussed later in this analysis. 


\section{Barriers to Implementation}

The barriers to adopting clean cookstoves in many homes deals with the high prices associated with stoves. Men tend to be the decision makers for expenditures for a household, although they are often not the ones cooking. This makes it difficult for women to purchase a clean cookstove for their family (Global Alliance for Clean Cookstoves, 2013). Besides cost, barriers to adoption include lack of knowledge of many of the benefits of stoves, ranging from health benefits, economic savings, and others. The benefits and costs of clean cookstoves are summarized in Table 2.

There are barriers from both the demand-size, the households that adopt clean cookstoves, as well as from the supply-side, the agencies and organizations supporting intervention and pilot programs. For many families, there is insufficient understanding of the benefits and costs associated with clean cookstoves. Some organizations suggest that if these connections were well known and clearly communicated to families, adoption rates of the stoves would increase.

From the perspective of suppliers of clean cookstoves, the challenges of getting users to adopt the stoves often deal with a lack of resources. This can come in the form of monetary resources to support technology development, provide subsidies, and overall program costs of intervention and pilot programs. There is also a lack of human capital to carry out such programs, especially in rural areas that lack supportive infrastructure.

As demonstrated in Table 2, the benefits from both the demand side and supply side are vast and range from health benefits, to economic benefits, to environmental and general well-being benefits. One way in which to overcome the costs associated with clean cookstoves is to provide a sustainable financing structure to lessen the burden on suppliers. 
Table 2. Overview of benefits and costs of clean cookstoves. Modified from (Malla \& Timilsina, 2014).

\begin{tabular}{|c|c|c|}
\hline & Demand-side (user) & Supply-side \\
\hline \multirow[t]{6}{*}{ Benefits } & Health & Environment \\
\hline & $\begin{array}{ll}\text { - } & \text { Morbidity } \\
\text { - } & \text { Mortality }\end{array}$ & 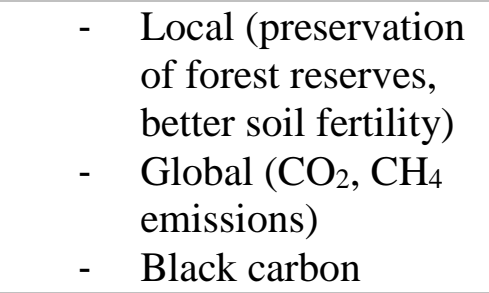 \\
\hline & Economic & Economic \\
\hline & $\begin{array}{ll}- & \text { Time savings } \\
- & \text { Fuel/fuel cost } \\
& \text { savings }\end{array}$ & $\begin{array}{ll}\text { - } & \text { Profit } \\
\text { - } & \text { Market development } \\
\text { - } & \text { Carbon finance }\end{array}$ \\
\hline & Other & Other \\
\hline & $\begin{array}{ll}\text { - } & \text { Cleanliness } \\
\text { - } & \text { Aesthetic gains } \\
\text { - } & \text { Social status gain } \\
\text { - } & \text { Saving fertilizers } \\
& \text { (biogas) }\end{array}$ & $\begin{array}{ll}\text { - } & \text { Skill development } \\
\text { - } & \text { Job creation } \\
\text { - } & \text { Community } \\
& \text { engagement }\end{array}$ \\
\hline \multirow[t]{4}{*}{ Costs } & Cost of clean cookstoves & Market intervention \\
\hline & Fuel cost & $\begin{array}{ll}\text { - } & \text { Subsidies } \\
\text { - } & \text { Fuel cost } \\
\text { - } & \text { Program costs }\end{array}$ \\
\hline & Maintenance cost & Trainings \\
\hline & Others & $\begin{array}{l}\text { Monitoring and quality } \\
\text { control }\end{array}$ \\
\hline
\end{tabular}




\section{Needs Assessment for a Sustainable Clean Cookstove Program in India}

\section{History of National Cookstove Programs}

India has attempted a variety of clean cookstove initiatives over the past few decades, none of which has truly penetrated the market for clean cookstove adoption. The first national program was founded in 1983 as a series of pilot programs that worked towards achieving several goals: conserving fuel, reducing smoke emissions in the cooking area, keeping kitchens clean, reducing deforestation, lessening women's drudgery, reducing cooking time, and improving employment opportunities for the rural poor (Barnes et al., 2012). While a valiant attempt, this program failed due to its overreliance on targets, lack of field monitoring and evaluation, and failure to penetrate the market (Barnes et al., 2012). The program's short-term impacts raised the percentage of household with improved biomass cookstoves to $5 \%$ by 2006 . However, this dropped to $0.3 \%$ by 2013 (Blunck, 2013).

More recently, the Ministry of New and Renewable Energy (MNRE) launched the National Biomass Cookstove Initiative (NBCI) in 2009 with the intention to develop "the next generation of household cookstoves, biomass processing technologies and deployment models (Blunck, 2013). One of the major differences between these two national initiatives is the NBCI is working to avoid generating pollution in the first place and not just moving it to the outside of the house via a chimney, as was done in the first program (Venkataraman, Sagar, Habib, Lam, \& Smith, 2010). NBCI has a focus on efficient use of fuel for cooking, as well as modern fuel generation. 


\section{The Paris Agreement}

The United Nations Framework Convention on Climate Change (UNFCCC) was initiated in 1994 with the ultimate objective of "stabilization of greenhouse gas concentrations in the atmosphere at a level that would prevent dangerous anthropogenic interference with the climate system" (United Nations Framework Convention on Climate Change, 2014). There are currently 194 countries that make up the Parties to the Convention, with developed countries leading the way for action and policy. These countries are under the spotlight due to the fact that many of the past and current greenhouse gas emissions have come from industrialized countries. These countries are collectively referred to as Annex II, and were tasked with reducing greenhouse gas emissions to below 1990 levels by the year 2000. While some already reached that goal, many countries have a substantial amount of work to do and must submit reports on changes to policies and plans to the UN, as well as maintain an emissions inventory.

Currently the developed or industrialized countries are being held to a higher standard when it comes to climate action. This is partly due to a difference in economic development, which is essential for many developing countries. Countries that are struggling with economic development could be further hindered by the challenges of climate change. Thus, developed countries are called upon to assist developing countries in a variety of ways to address climate concerns by providing resources that many developing countries do not have.

After years of conventions without substantial agreement on the actions developed countries need to take, the $21^{\text {st }}$ Convention (COP 21) in Paris last year led to the Paris Agreement, a momentous occasion, as noted in Figure 3. The Agreement "seeks to 
accelerate and intensify the actions and investment needed for a sustainable low carbon future" (United Nations Framework Convention on Climate Change, 2016). The goal of the Agreement is to reduce global temperatures two degrees Celsius below pre-industrial temperatures (i.e. before 1750). In order for the Agreement to enter into force, 55 Parties to the Convention that release $55 \%$ of the world GHG emissions must be ratified.

The Agreement includes 29 articles, three of which will be discussed as relevant to this paper. The Agreement has been signed by 175 countries thus far, but still needs to be ratified by most, especially the larger contributing countries.

Article 4 of the Agreement addresses mitigation by requiring all Parties to submit nationally determined contributions and related measures to the UNFCCC every five years, with each update being more aggressive than the last (United Nations Framework Convention on Climate Change, 2016). There are different expectations for developing and developed countries. Developing countries are encouraged to enhance their mitigation efforts and alter their economy-wide targets over time, while developed countries are expected to take the lead and undertake absolute economy-wide targets (United Nations Framework Convention on Climate Change, 2016).

Articles 9, 10, and 11 are detail how developed countries should support developing countries through a variety of means. Developed countries are committed to submit indicative information on future support every two years, including projected financial support (United Nations Framework Convention on Climate Change, 2016). These articles also outline the financial mechanisms of the Agreement in the form of the Green Climate Fund, as well as climate-safe technology development and capacity building activities. 


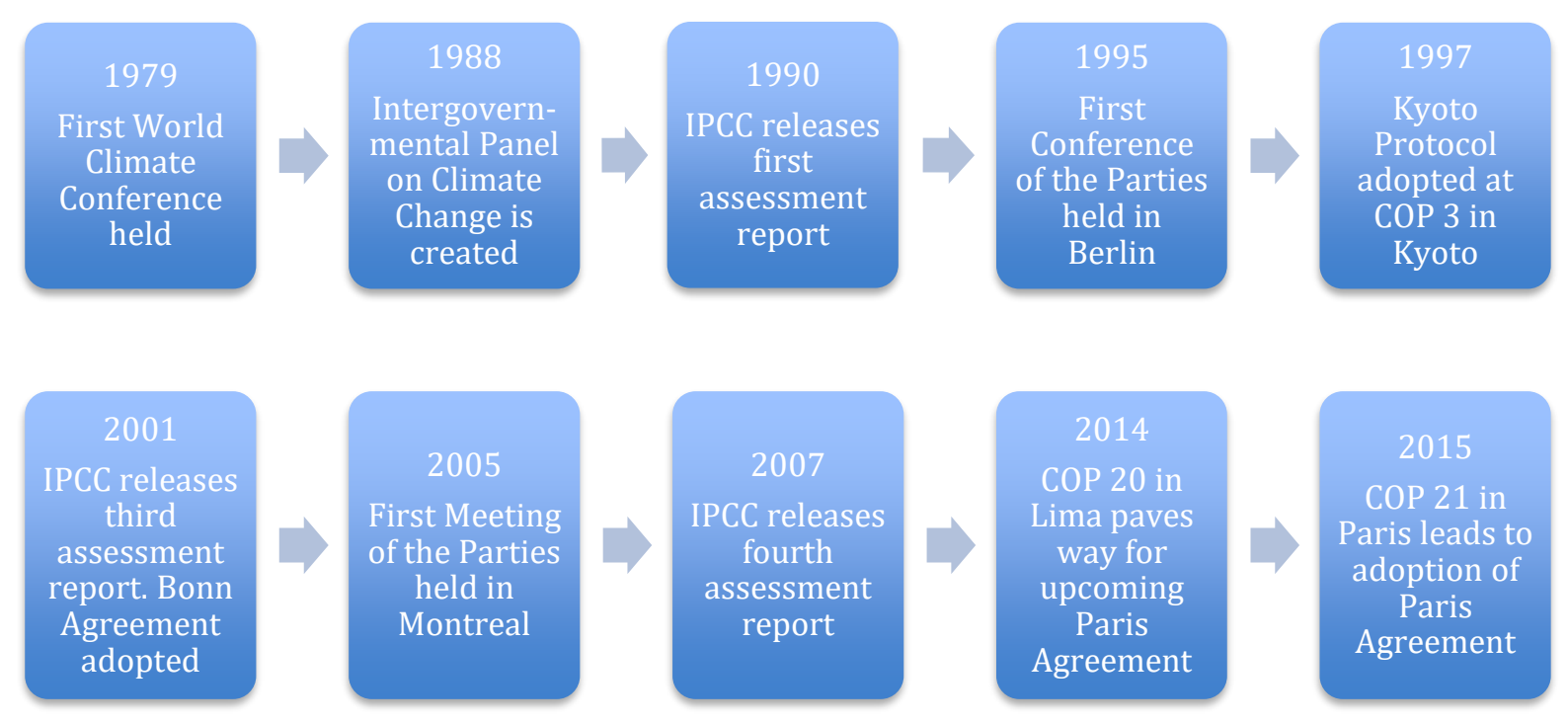

Figure 3. History of Paris Agreement. Modified from "Background on the UNFCCC: The International Response to Climate Change."

\section{$\underline{\text { India's INDC }}$}

A crucial component to the Paris Agreement is the submission of each member county's Intended Nationally Determined Contributions (INDC). Each INDC identifies existing conditions of a country and sets up a framework to improve those conditions, often through mitigating GHGs and adapting to climate change.

India has currently signed the Paris Agreement, but the Parliament of India has not yet ratified it. India contributes $4.14 \%$ of global emissions, the third largest country emitter. The country accounts for $2.4 \%$ of the world's land area, yet supports about $17.5 \%$ of the world's population, about 1.2 billion people (Government of India, 2016a). Of those 1.2 billion people, about 30\% (363 million) live in poverty, a number just over the entire population of the United States. While many live in and around the urban centers of India, they lack basic access to clean water, sanitation, and electricity. About $30 \%$ of the population rely on solid biomass for cooking, often using a stove without proper ventilation 
or filters. The per capita energy consumption in India is $917 \mathrm{kWh}$, approximately one third of the world's average consumption (Government of India, 2016a).

As shown in Figure 4, the energy production by different sources has remained fairly steady over the past few decades. Coal remains the largest source of energy generation in India, although there has been recent growth of both renewable energy development and nuclear energy. It is important to note the energy sources in India when understanding the alternatives to biomass cookstoves, as the current dominant source of energy does not assist in overcoming neither health nor climate risks.

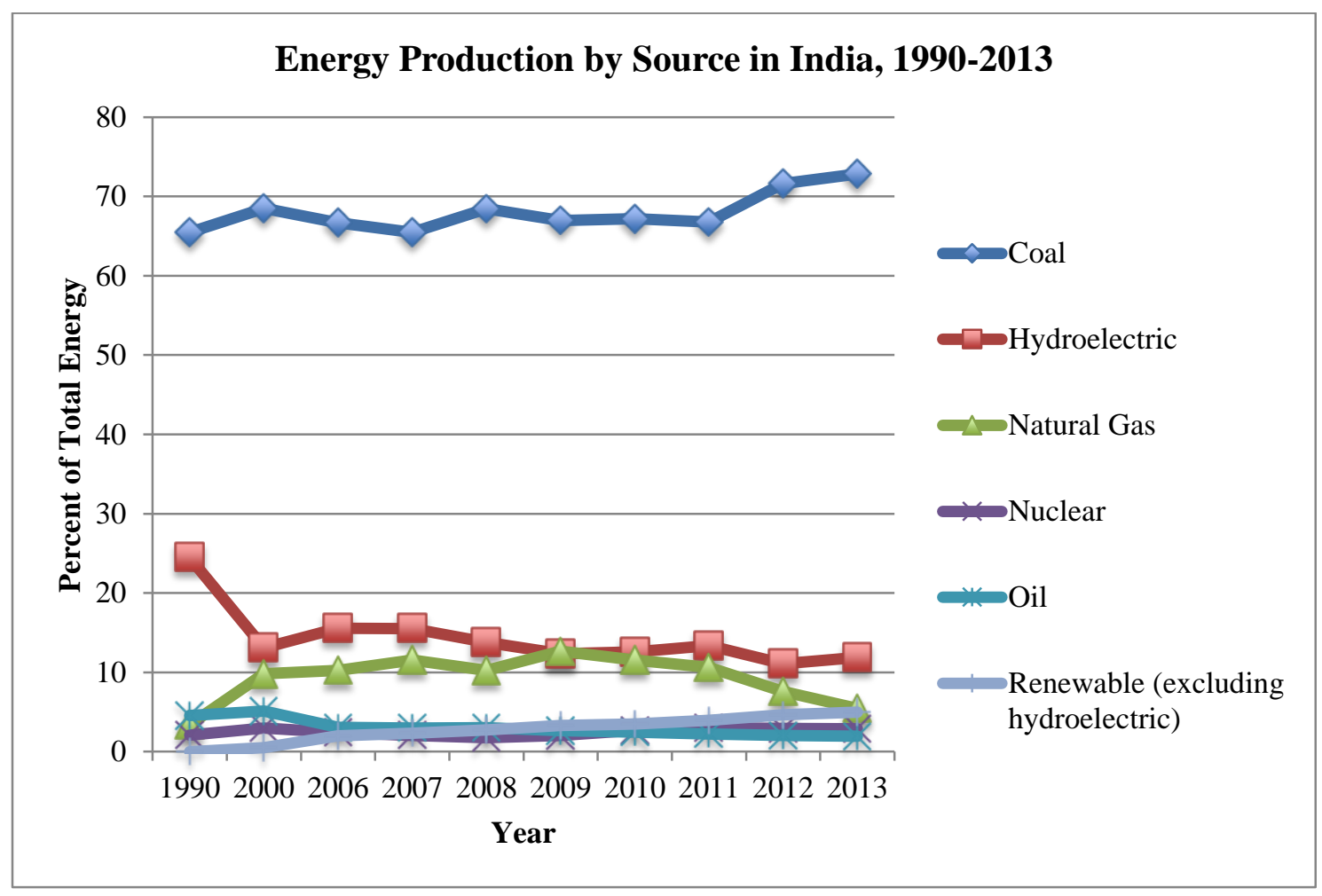

Figure 4. Energy Production by Source in India, 1990-2013. Data from database: World Development Indicators, 2016.

While India faces many challenges, the country is ahead of many in regards to desire to take action and appreciation for the natural environment. As stated in Article 48A of the Constitution of India, "The State shall endeavour to protect and improve the environment and to safeguard the forests and wildlife of the country." 
Biomass energy makes up about $18 \%$ of the total primary energy use in India, and more than $70 \%$ of the country's population depends on it, partly for cooking purposes (Government of India, 2016a).

India's INDC details the funding mechanisms in place to assist with mitigation and adaptation actions, as well as acknowledging some of the challenges. One of the funding mechanisms relevant to clean cookstoves is the National Clean Environment Fund, a tool that finances clean energy, technologies, and related projects. In 2014-15, the fund assisted 46 projects with $\$ 2.7$ billion (Government of India, 2016a).

The INDC commits to addressing funding issues in its action statement, as demonstrated in the seventh statement: "To mobilize domestic and new \& additional funds from developed countries to implement the above mitigation and adaptation actions in view of the response required and the resource gap" (Government of India, 2016a). The resource gap to which the INDC refers it substantial; there have been many estimates on how much it will cost to carry out the actions introduced in the INDC, and one such estimate by the National Institution for Transforming India Aayog suggests the mitigation activities alone for moderate low carbon development would cost around $\$ 834$ billion until 2030 (Government of India, 2016a).

\section{The Need for a Sustainable Clean Cookstove Program}

India has partnered with the Global Alliance for Clean Cookstoves to boost the clean cookstove market. This partnership is organized through the Ministry of New and Renewable Energy and the Ministry of Health, with a target of reaching five million households by 2017 (Global Alliance for Clean Cookstoves, 2016a). According to the World Health Organization, about $25 \%$ of the 4.3 million global premature deaths due to 
HAP occur in India each year (Global Alliance for Clean Cookstoves, 2016a). More than 800 million people are impacted by exposure to HAP in India (Global Alliance for Clean Cookstoves, 2016a). As depicted in Figure 4, the mortality rate of children under the age of 5 has dropped over the past few decades, but remains slightly higher than the world average. A national clean cookstove program could help reduce this rate.

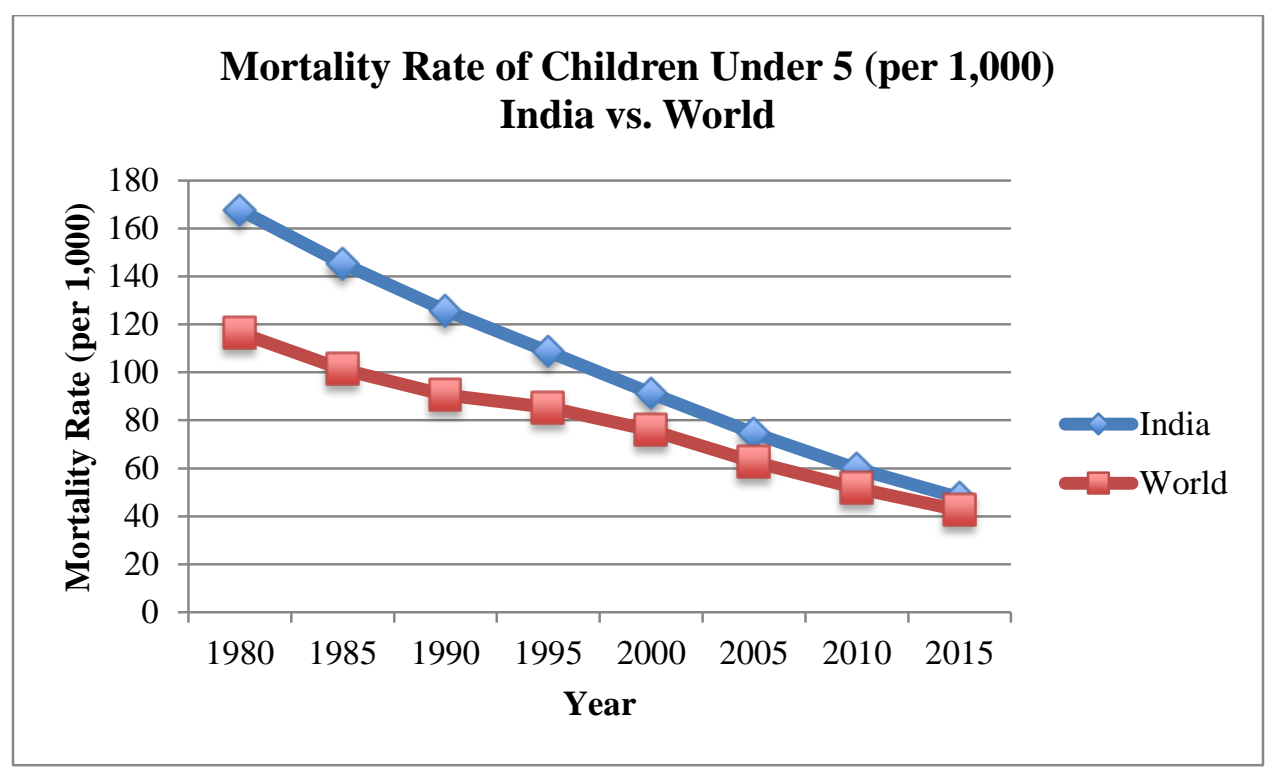

Figure 5. Mortality Rate of Children Under 5 (per 1,000) India vs. World. Data from database: World Development Indicators, 2016.

Over $65 \%$ of the country continues to rely on solid biomass to fuel their cooking needs. The use of these fuels remains a significant and unequal health risk, especially for women. Ninety percent of those exposed to the burning of these solid biomass fuels are women, while many women spent up to eight hours per day cooking, and about a fifth of that time is spend collecting fuel (Global Alliance for Clean Cookstoves, 2013). Figure 5 shows the proportion of households using solid biomass (firewood, crop residue, dung cake, and coal) versus those using modern fuels such as kerosene, LPG, electricity and others. As expected, the rural households rely on firewood for their fuel source far more heavily than those in urban areas. 


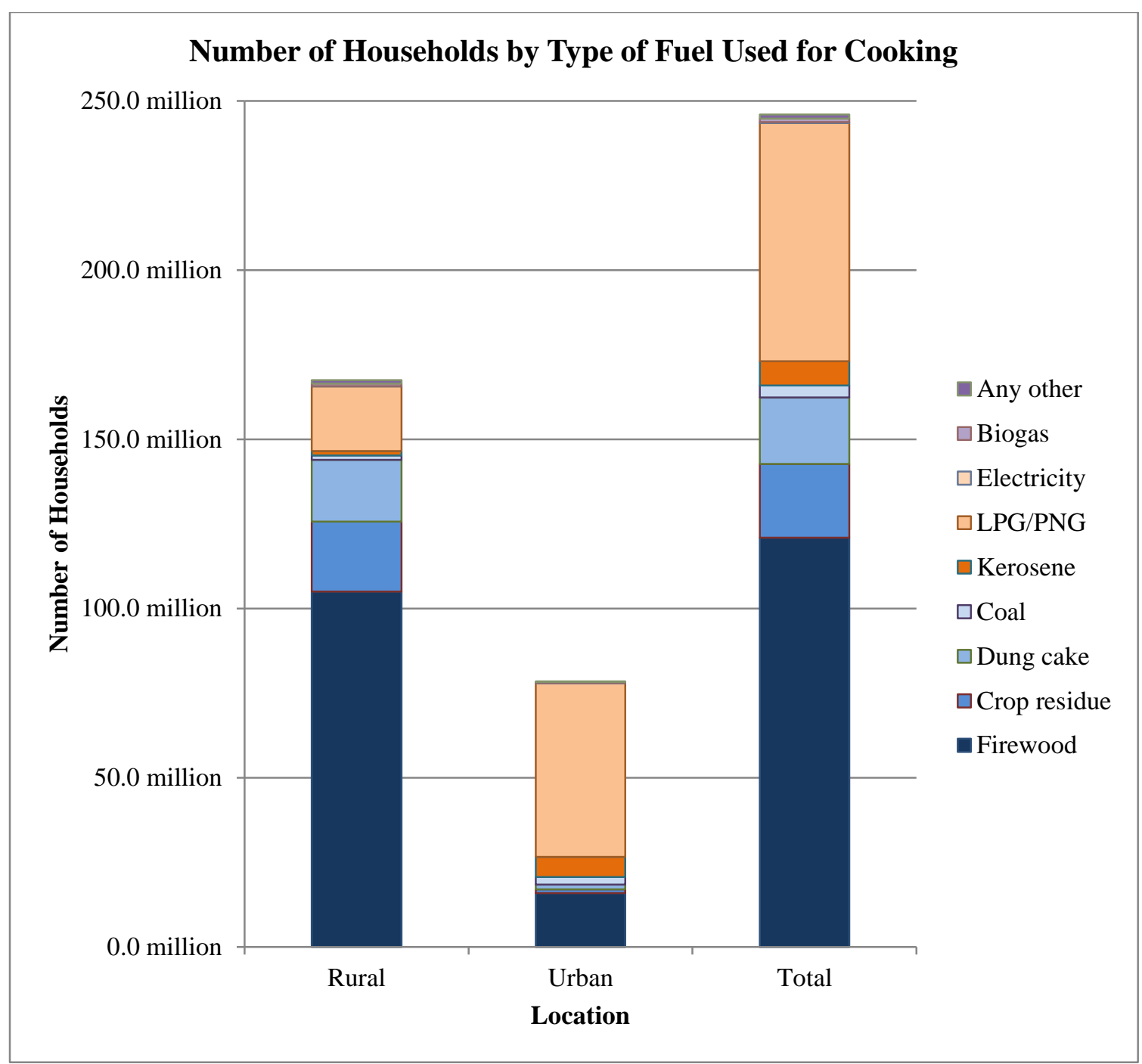

Figure 6. Number of Households by Type of Fuel Used for Cooking. Source: Census of India 2011.

The size of the cookstove market in India is about 235 million households, with $45 \%$ making up the challenging market segment of rural households that do not pay for fuel (Global Alliance for Clean Cookstoves, 2013). Switching to a clean alternative often means paying for a clean energy source, such as electricity. Penetrating the market with this type of paid energy source is one of the most difficult barriers to a clean cookstove program. This challenge will continue for the next few decades, as rural populations in India are expected to increase for another decade before leveling off. This has implications 
for fuel demand in rural areas, which often lack access to infrastructure to transport energy. Although deemed "rural," many of the areas discussed under that term refer more to their location than the population, as rural areas can be densely populated.

However, as demonstrated in Figure 7, the urban population is growing at an even faster rate and is expected to reach the same number of people living in rural areas of India by 2050. This will also increase the demand for fuel for cooking, but perhaps a demand for modern fuels, as Figure 6 shows that LPG is currently the dominant modern fuel used in urban households.

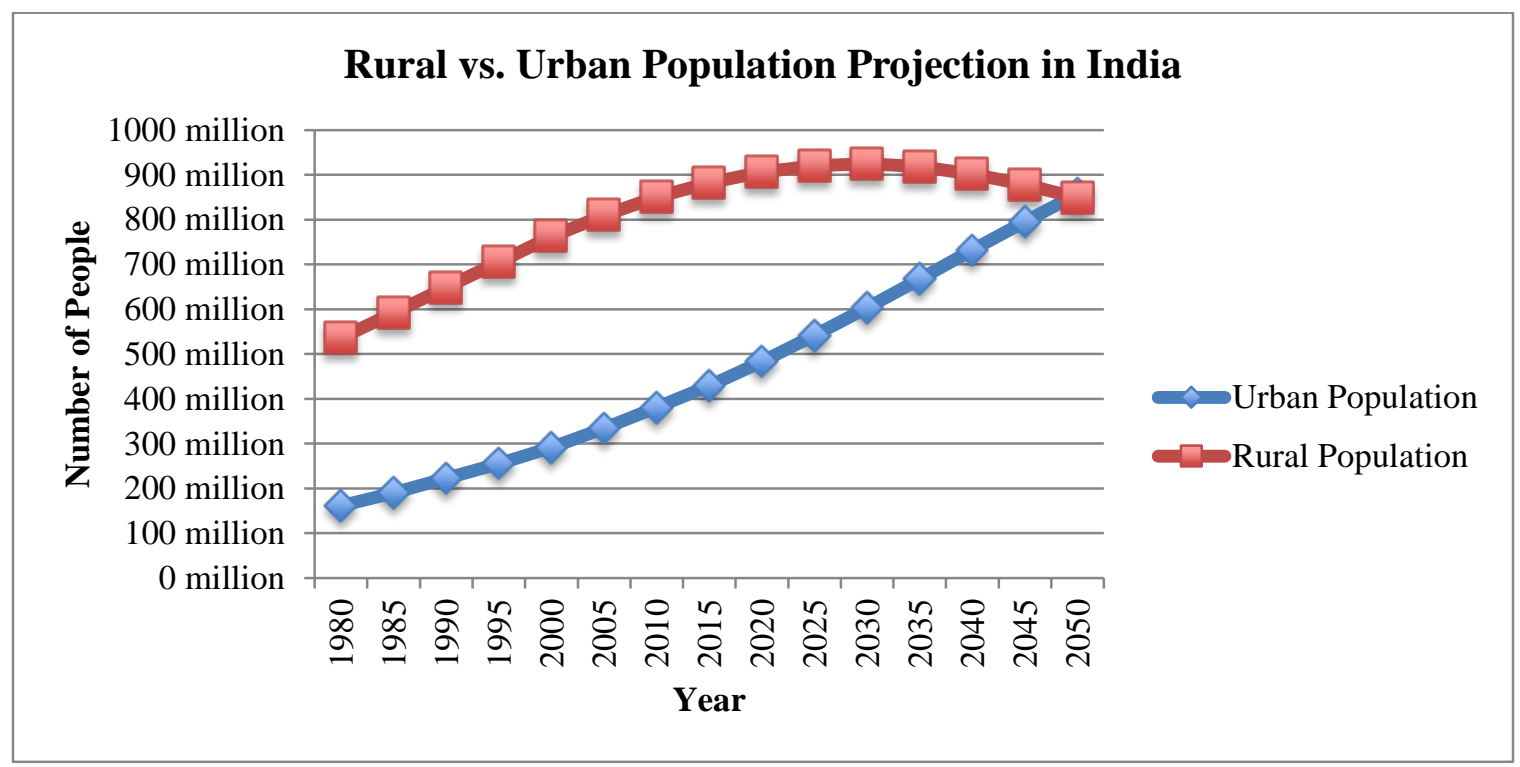

Figure 7. Rural versus Urban Population Projection in India. Source: Health Nutrition and Population Statistics: Population estimates and projections. Retrieved from World DataBank, 2016.

The Global Alliance for Clean Cookstoves has identified the biggest challenges for market penetration of clean cookstoves in India: "lack of awareness of the problem among consumers, a dearth of sustainable financing sources, variable government policies which can spoil the market by introducing subsidies, and challenges in identifying effective partners to conduct rural distribution" (Global Alliance for Clean Cookstoves, 2013, p. 5). 
This analysis will address the sustainable funding challenge that is hindering the ability of the clean cookstove market to succeed.

India has recently initiated new systems to scale up the clean cookstove efforts, through both the National Biomass Cooking Initiative (NBCI) and the National Clean Energy Fund, although both have been targeted toward the private sector and have been slow to start (Global Alliance for Clean Cookstoves, 2013).

\section{$\underline{\text { Existing Goals }}$}

Through many recent initiatives, India has demonstrated interest in improving energy access, wellbeing, and conservation through various goals and policies. India adopted the National Action Plan on Climate Change (NAPCC) that features eight missions to help reduce emissions and adapt to a changing climate. The National Mission for a Green India (Mission) focuses on the importance of good forestry practices with an understanding that "the forestry sector has on environmental amelioration through climate mitigation, food security, water security, biodiversity conservation and livelihood security of forest dependent communities" (Ministry of Environment and Forests, 2015, p\#). With this underlying premise, the Mission includes targets to lessen the impact of harvesting fuelwood. For example, Target 3.3.1 states "Adoption of improved fuelwood-use efficiency and alternative energy devices by project area households," suggesting technology improvements for fuel efficiency and alternative fuels with regards to cooking (Ministry of Environment and Forests, 2015, p. 3).

Besides fuelwood conservation, there have been national goals towards adoption of LPG for cooking needs. The Vision 2015, a national initiative, aims to increase LPG population coverage to $75 \%$ by 2015 (Government of India, 2012). However, other studies 
have noted that LPG may not be good alternative fuel, as its price is likely to increase faster than rural household incomes since it is a petroleum product and is subject to price instability (Venkataraman et al., 2010).

Recently the Indian government committed to providing all Indians with 24 hour electricity access by 2019 (Waskow \& Bapna, 2015). This would make acquiring fuel for clean cookstove adoption easier and potentially more sustainable, if the country diversifies its energy portfolio away from coal.

\section{A New National Program}

As mentioned previously, while there is the National Biomass Cooking Initiative (NBCI), it has been slow to start and focuses on the private sector. The program was based off a global competition for a clean cookstove that could be versatile, however the competition never took off (Chandrashekhar, 2015). Further, the leadership at the Ministry of New and Renewable Energy (MNRE) moved to other posts in 2014 with a new election and many other officials in the Ministry did not support the NBCI (Chandrashekhar, 2015). There is an urgent need for a new national clean cookstove program. The new program should be one that builds off the lessons learned from various state pilot programs, previous national programs, as well as successful programs of other countries such as China. While price has historically been a significant barrier of adoption, the new program should be wary with using subsidies to jumpstart the market. As research has shown, significant subsidies toward the cost of improved stoves had the worst records of usage in pilot programs (Barnes et al., 2012). Rather, if subsidies are used they should go toward technical assistance, quality control, and market testing (Barnes et al., 2012). 
The new national program should focus on social acceptance of the stoves, and field monitoring and evaluation of the technical performance of the stoves, aspects that were lacking in the first national program (Barnes et al., 2012). There is no one-size-fits-all ability for a clean cookstove program. There must be a variety of types and sizes of stoves to meet the diversity of fuel types and cooking styles throughout India. As Barnes et al. suggest, "successful programs require both national coordination and development of technical infrastructure that can support stove standards and design” (2012, p. 128). Another option of how the climate financing could assist a national program is through allowing customers to pay monthly or bimonthly installments to purchase clean cookstoves that have been approved through the program, as suggested by Barnes et al. (2012). 


\section{Funding a New National Program with U.S. Assistance}

\section{$\underline{\text { A History of Partnerships }}$}

The U.S. and India have had several partnerships to finance climate initiatives. Recently, the two nations have been working together through the Partnership to Advance Clean Energy (PACE), which began in 2009. PACE is aimed at accelerating inclusive, low carbon growth through the use and development of clean energy technologies (The Department of Commerce et al., 2015).

Currently USAID is supporting the clean energy and sustainable landscapes (forestry) priority sectors under the India's NAPCC (U.S. Agency for International Development, 2016). The sustainable landscapes program is assisting India's initiative, Reducing Emissions from Deforestation and Forest Degradation (U.S. Agency for International Development, 2016).

\section{$\underline{\text { India's Financial Contribution to Clean Cookstoves }}$}

Historically, the amount of funding available to Indian national initiatives for clean cookstoves has been minimal. For example, the MNRE funded a clean cookstove program as part of their Renewable Energy for Rural Applications budget, which equated to about \$3 million USD for 2015-2016 (Government of India, 2016b). However, this program does not take into account urban or semi-urban households. Another more recent program through MNRE was the Unnat Chulha Abhiyan Programme that began in 2014 with the

objective of developing and deploying improved biomass cookstoves to all types of settlements in India with a subsidy of \$1.7 million USD (Government of India, 2016b), however the overall five year plan for the program include about $\$ 44$ million USD, 
although it is unclear where this funding is expected to come from (Ministry Of New and Renewable Energy, 2014).

\section{$\underline{\text { A New Funding Structure }}$}

A new program could be sustainably funded through a partnership with USAID and the Indian Ministry of New and Renewable Energy and the Ministry of Health. Due to the lack of action from the NBCI, it is essential to have multiple ministries working on the new national program. This will mean the two ministries share the burden of responsibility, and may bring about more funding, as this is both a climate and health initiative.

As explained previously, the Global Alliance for Clean Cookstoves currently partners with the two ministries to work towards achieving the goal of reaching five million households by 2017. The Alliance brings an abundance of resources and expertise that is needed for a sustainable and effective clean cookstove program. This organization has researched many of the barriers of clean cookstove adoption and avoiding stove stacking. The Alliance is simply underfunded, especially when it comes to achieving goals in country as large as India. The funding from USAID and the EPA could be transferred to the Indian Renewable Energy Development Agency, a non-banking financial company with the Reserve Bank of India that offers loans to new and renewable energy projects (India, 2016), as shown in Figure 8. This could be the funding source for the national initiative that will be constant until at least 2025, as detailed in the Paris Agreement. 


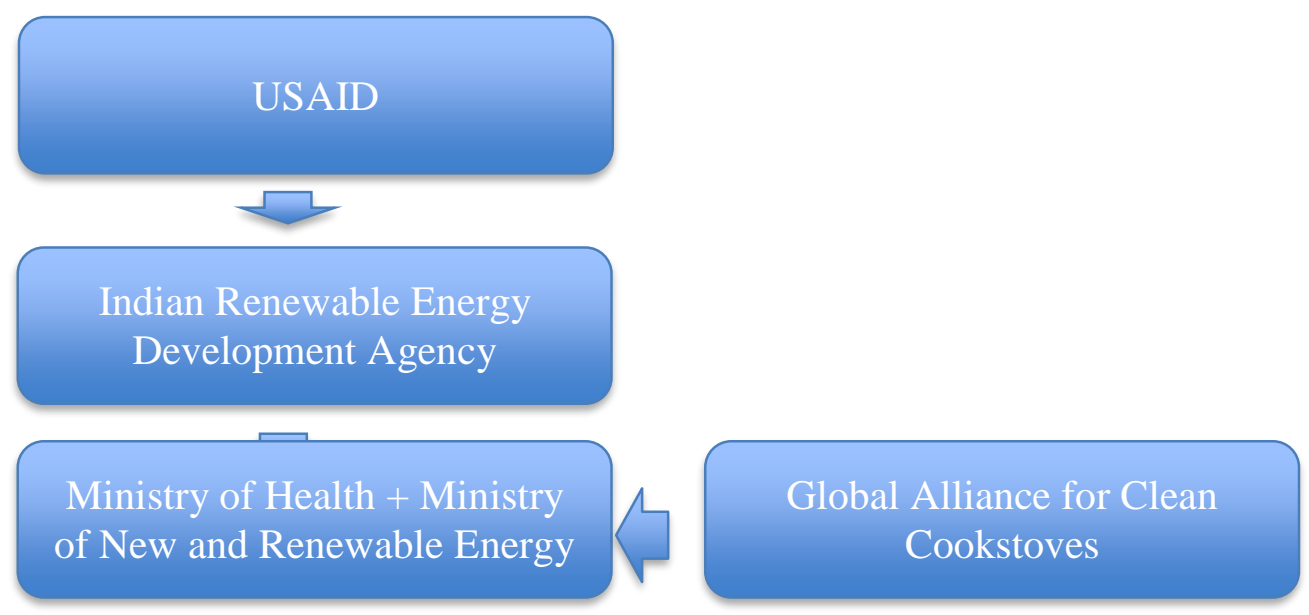

Figure 8. Funding Flowchart for New National Program with U.S. Assistance.

As part of the Paris Agreement, developed countries have pledged to give $\$ 100$ billion per year to developing countries until 2025 (Steer, 2016). The U.S. in particular has committed to doubling its annual public grant funding for adaptation to $\$ 800$ million by 2020 (Steer, 2016). The new national clean cookstove program would be considered both a mitigation and an adaptation action, potentially being able to utilize this funding. This pledge demonstrates a commitment by the U.S. to support international climate initiatives.

The World Resources Institute recommends that the U.S. and India can improve their relationship on climate and energy through providing financial assistance from U.S. departments like the U.S. Agency of International Development (USAID) and the Department of Energy (DOE) (Waskow \& Bapna, 2015). The DOE has international programs for technology development of clean energy, and is a member of the International Energy Agency, working to improve clean energy security globally.

USAID has been funding several programs in India, many of which could be considered potential funding sources for a cookstove program. These programs include the Global Health Programs, Development Assistance, and the Economic Support Fund. As 
demonstrated by Figure 9, there has been a shift in the funding requested by India from economic support to development assistance. Meanwhile, health programs remains the highest in terms of requested and received funding. A clean cookstove program can be considered a public health initiative and a development assistance initiative, attempting to transition away from high household air pollution and deforestation for biomass fuel.

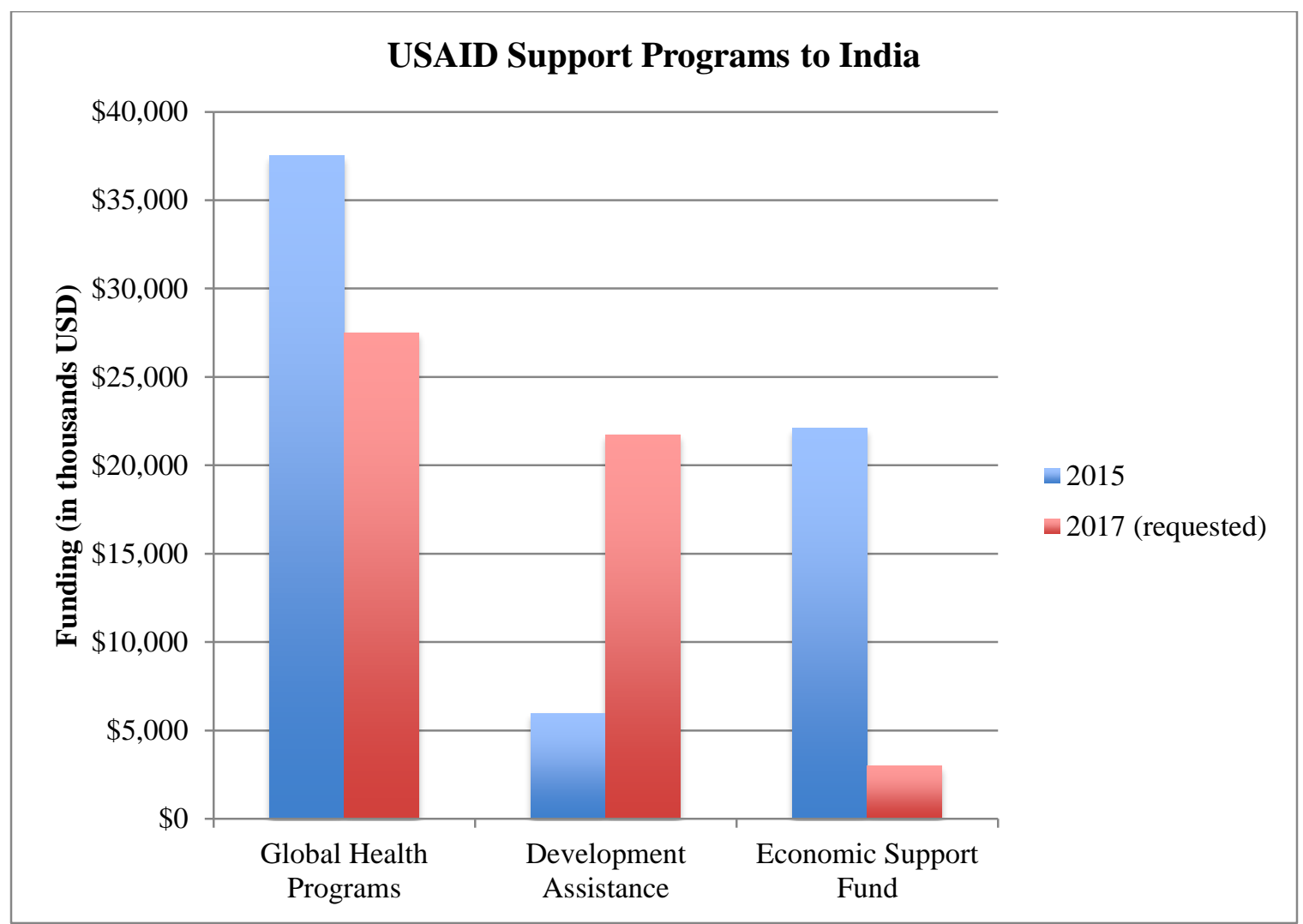

Figure 9. USAID Support Programs to India. Source: 2016 Congressional Budget Justification.

Considering the restrictions of the Paris Agreement, and the fact that the $\$ 100$ billion that Annex II countries must provide to developing countries will not come to term until 2020, I recommend a five-year strategy to create a new national program. The funding for such a program needs to be substantial when compared with previous national programs. As is noted by the World Resources Institute, the funding "sources, instruments and channels... remain ambiguous" to reaching the $\$ 100$ billion goal (Westphal, Canfin, 
Ballesteros, \& Morgan, 2015, p. 1). Since the clean cookstove program can be viewed as both a mitigation and an adaptation action, funding may be able to come from multiple mechanisms. However, mitigation funding is considered easier to obtain, as predictions for funding favor mitigation over adaptation (Westphal et al., 2015). In India in particular, as noted previously, the amount of funding needed to implement all the mitigation actions outlined in the INDC equates to about $\$ 834$ billion by 2030. Although the Parties of the Agreement committed to the funding of $\$ 100$ billion, a stipulation of COP 16 in Cancun included that funding would come from a "wide variety of sources, public and private, bilateral and multilateral, including alternative sources of finance" (Westphal et al., 2015, p. 5).

Table 3. United States Climate Finance Contributions in 2012. Modified from (Westphal et al., 2015).

\begin{tabular}{|c|c|c|}
\hline \multirow[t]{3}{*}{ Multilateral } & Mitigation & \$324.78 million \\
\hline & Adaptation & $\$ 53.7$ million \\
\hline & Cross-Cutting & \$69.91 million \\
\hline \multirow{4}{*}{$\begin{array}{l}\text { Bilateral/Regional/Other } \\
\text { Channels }\end{array}$} & Mitigation & \$1,496.61 million \\
\hline & Adaptation & \$339.52 million \\
\hline & Grant Finance & $\$ 813.30$ million \\
\hline & $\begin{array}{l}\text { Non-grant } \\
\text { Finance }\end{array}$ & \$1,022.84 million \\
\hline \multicolumn{2}{|l|}{ Total } & $\$ 2,284.52$ million \\
\hline
\end{tabular}

The United States has historically provided large contributions to both mitigation and adaptation activities internationally. As demonstrated in Table 3, the U.S. contributed almost $\$ 1.5$ billion in 2012 alone to mitigation efforts and over $\$ 53$ million for adaption. While this demonstrates a continued commitment to assisting international climate initiatives, it does not specify how much is being provided to each country. 


\section{The Five-Year Plan}

The new national clean cookstove program could be funded through a partnership with the United States and assistance from the Global Alliance for Clean Cookstoves, the Shell Foundation, and other financing organizations. Since the Paris Agreement deems 2020 as the year for initiatives to spring into action, it seems a fitting time for a new clean cookstove program. The program would need a substantial amount of funding from the start to get the program up and running. As deployment occurs, market penetration is expected if areas are correctly targeted, thus the amount of funding supporting deployment should decrease over time. Using the Unnat Chulha Abhiyan (UCA) Programme as a small-scale model of the funding necessary, the proposed national plan should be a scaled-up version. The target of the UCA Programme was 2.75 million clean cookstoves adopted over five years (Ministry of New and Renewable Energy, 2014).

The new program would feature many of the same characteristics outlined in the UCA Programme. The funding should support deployment activities, technical assistance, administrative duties, monitoring and evaluation, and educational and outreach activities. Although there are already 15 models of clean cookstoves that have been approved by the MNRE through performance testing as of 2014, there should remain an emphasis on technological development (Ministry of New and Renewable Energy, 2013). The UCA Programme focuses on improved biomass cookstoves, but research has demonstrated that solid biomass fuels are not the best option in terms of both health and climate. As India continues its rapid development, there may be an opportunity to 'leapfrog' energy infrastructure and establish a stronger electric grid 
nationally, as per the 2019 goal of 24-hour electricity access. Currently, 78.7\% of the Indian population has access to electricity (The World Bank, 2016).

The current implementation plan for the UCA Programme is robust and well thought out. Rather than re-inventing the wheel, the new national program should essentially build off of the current progress of the UCA Programme, with larger targets and increased funding.

There are still many millions of households that need clean cookstoves in their homes, as the market is estimated to be about 235 million households (Global Alliance for Clean Cookstoves, 2013). Thus, the new national program should aim to deploy 100 million clean cookstoves over five years, from 2020 to 2025 . This is in addition to the existing goals of the UCA Programme of 2.75 million and the Global Alliance for Clean Cookstoves of 5 million cookstoves. Though this is a massive scale-up in the program, it is not unheard of. In the 1990s, China implemented a clean cookstove program that deployed 150 million clean cookstoves. While there are political and organizational difference between India and China, strategies employed in the Chinese program could be used in an Indian one. With support from the United States, this can be an achievable program.

Table 4 outlines a potential five-year budget for a new national program in India, comprising the same items that are currently funded in the UCA Programme. The next sections delve into what each item should focus on in a new program and how this scenario could play out. To better explain the funding for a new cookstove program, the scaled-up version could simply use the current UCA Programme's funding distribution and increase each item proportionally. These proportions are shown in Figure 10. 


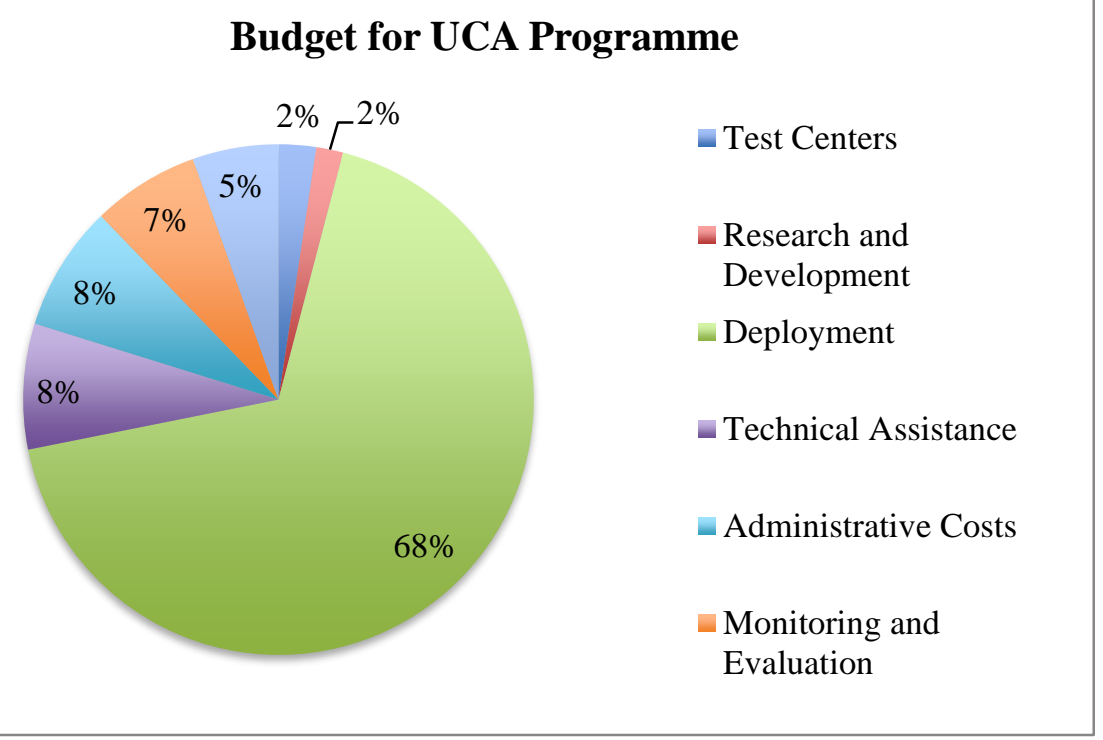

Figure 10. Budget for UCA Programme by Percentage.

Table 4. Five-Year Budget for New National Program.

Item

Funds Required (in millions USD)

Test Centers $\$ 30.0$

Research and Development

$\$ 22.5$

Deployment $\$ 870.0$

Technical Assistance

$\$ 100.0$

Administrative Costs $\$ 50.0$

Monitoring and Evaluation $\quad \$ 90.0$

Education and Outreach Activities $\quad \$ 72.0$

Total $\$ 1,234.5$

\section{$\underline{\text { Test Centers }}$}

Test centers are facilities in which stoves are designed and tested for a variety of uses and fuels. Due to the diversity of cuisines across the country that often change with geographic areas and cultures, there needs to be viable options to replace traditional cookstoves with options that improve air quality and reduce environmental implications. New stoves should consider fuel accessibility and price, stove price, convenience, and 
attractiveness and cleanliness in the home. Further, stoves that are deployed should improve fuel efficiency, reduce cooking time, improve household air quality, and handle a diversity of cooking services (Barnes et al., 2012).

The current UCA Programme has been developing improved biomass cookstoves, but a scaled-up program should focus on more modern fuels that may be accessible and cheaper in the future, such as electricity and LPG. Interestingly, a pilot program in India that tested fuel preferences found that households preferred an electric coil stove over two types of biomass-burning cookstoves (Global Alliance for Clean Cookstoves, 2015).

\section{$\underline{\text { Research and Development }}$}

Development of clean cookstoves, in association with the test centers, should include a communication aspect in which stove designers, producers, and users can all contribute to ensure stoves are efficient and effective. The lack of this component is cited as one of the downfalls of the previous national program in India (Barnes et al., 2012).

There should also be a component in the new national program to include market surveying to determine where demand is and what type of stove would be required (Barnes et al., 2012). The Global Alliance for Clean Cookstoves has conducted extensive market research in India and a new national program could build off their findings.

\section{Deployment}

To reach the millions of households that need clean cookstoves, there must be a system to transport the stoves to cities and more rural villages. This is often placespecific, as infrastructure support varies across the country. The Alliance has suggested a better understanding of the last mile; often stoves can reach urban areas but depending on 
local supply chains, getting stoves to rural areas can still be challenging (Global Alliance for Clean Cookstoves, 2012). There have been attempts to overcome this challenge, such as a pilot program in the state of Maharastra, India's third largest state, which provided large subsidies to distribute stoves in places that were challenging to reach (Barnes et al., 2012).

The UCA Programme's deployment activities include a network of ministries and organizations to distribute clean cookstoves. These partners include self-help groups that work under the National Rural Livelihood Mission, district coordinators of the midday meal scheme under the Ministry of Human Resource Development, and district coordinators of Anganwadi centers under the Ministry of Women and Child Development (Ministry of New and Renewable Energy, 2013).

Scaled-up deployment should continue to work through these previously initiated partnerships, as well as through other techniques. These could include door-to-door demonstrations of how clean cookstoves work, or providing community workshops to overcome the social and behavioral barrier often associated with clean cookstoves. To overcome the price barrier, rebates or vouchers could be used, as well as financing options over monthly or bimonthly installments. Studies have shown that if households invest in a clean cookstove themselves, they are far more likely to use it often and reduce the risk of stove stacking (Barnes et al., 2012).

Another method to avoid stove stacking is to provide villages with community stoves that are larger and capable of cooking for special events and celebrations that individual clean cookstoves cannot support. The UCA Programme includes two line 
items for deployment: one for individual household stoves and one for community stoves. For the purpose of this analysis, deployment is considered one line item.

\section{$\underline{\text { Technical Assistance }}$}

Technical assistance can be considered a component under both deployment, and education and outreach activities. Technical assistance can include trainings to help households understand how to use the stoves, as well as support to fix stoves. Ensuring working stoves can again lessen the risk of stove stacking. One of the criticisms of the previous national program was insufficient after-sales service as well as user training (Barnes et al., 2012).

\section{$\underline{\text { Monitoring and Evaluation }}$}

Monitoring both the technical performance of the clean cookstove and the social acceptance of the new technology is critical for the sustained success of a new national program. This is another component that was lacking in the last national program in India (Barnes et al., 2012). The UCA Programme has identified a strategy to assist with monitoring of the program through the use of a web-based system that uses photos taken on mobile devices (Ministry of New and Renewable Energy, 2013). As India continues to improve its electrical grid, this type of monitoring system is more feasible and would require less staffing resources.

\section{$\underline{\text { Education and Outreach Activities }}$}

One of the goals of a new national program should be to eliminate stove stacking, a behavioral norm in which households use multiple stoves for different cooking purposes. As long as households continue to use traditional cookstoves, there will still be 
health risks and environmental degradation. Public outreach and education are essential components to a successful nation program. The education should focus on understanding the health benefits, time savings, and reduced fuel use associated with clean cookstoves can change perceptions of clean cookstoves and encourage households to use only one stove. Studies have shown that many households have limited understanding of the adverse effects of traditional cookstoves and cooking practices (Lewis et al., 2015).

\section{Three-Pronged Approach}

As demonstrated in Figure 11, in order to strengthen the clean cookstove market, researchers recommend a three-pronged approach. First, the demand for clean cookstoves needs to be enhanced, which can be achieved through improved cookstove technologies, understanding the customers' needs, and assisting households with purchasing stoves and fuels (Global Alliance for Clean Cookstoves, 2012). Second, the supply of clean cookstoves must be strengthened through alterative funding sources such as climate finance, increasing access to clean fuels, and a better understanding of the market. Last, to foster an enabling environment for the adoption of clean cookstoves, there needs to be multiple levels of stakeholders at the local, national, and international levels, a strengthened method of monitoring and evaluating program effectiveness, and increased public outreach and awareness (Barnes et al., 2012).

Through the components outlined above, the new national clean cookstove program in India could achieve this three-pronged strategy and implement a sustainable and successful program that reduces health and climate implications. 


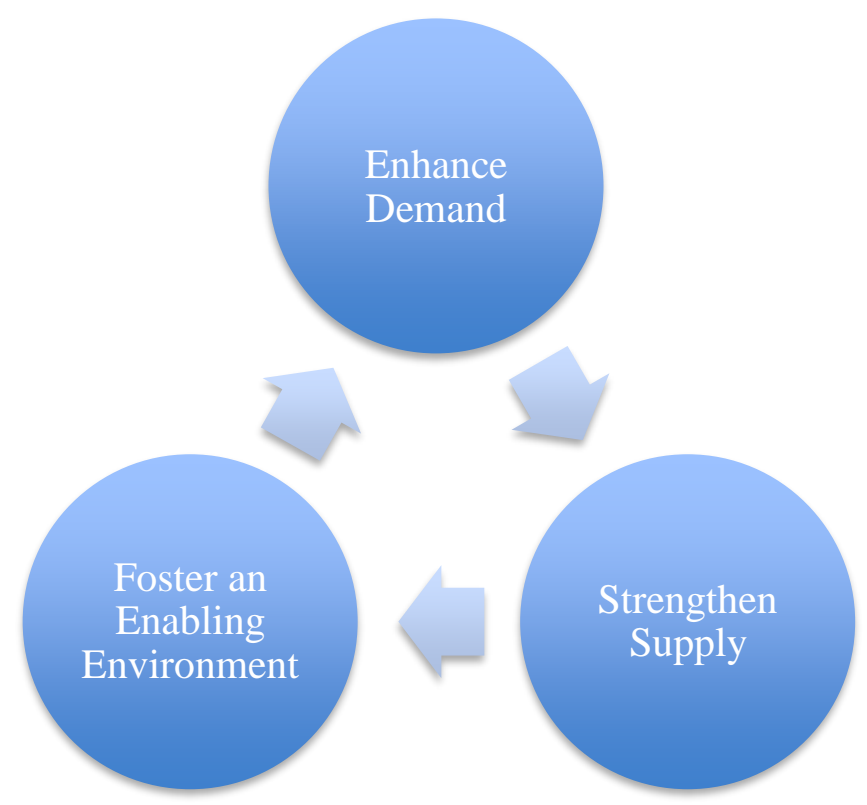

Figure 11. Strategy to Strengthen Clean Cookstove Market in India. Modified from (Global Alliance for Clean Cookstoves, 2012).

\section{$\underline{\text { United States' Contribution }}$}

The United States can contribute to this budget through allocating the USAID climate mitigation budget to support India's efforts. The program has the potential to decrease India's total GHG emissions by up to four percent (Malla \& Timilsina, 2014). With a combined effort with the Department of Energy's Office of International Affairs and the PACE initiative, India and the United States can view this program as an energy action. Since PACE began in 2009, the seven U.S. agencies working on the initiative have leveraged about $\$ 2.5$ billion for clean energy projects in India, although this is through public and private investment and does not translate as available funding, but could be used to assist with financing a new national program (The Department of Commerce et al., 2015).

There is also an opportunity to seek additional funding from foundations and other grant-awarding organizations. The Shell Foundation is one of the largest 
contributors to the Global Alliance for Clean Cookstoves and has been increasingly their spending per year on energy access initiatives. The foundation spent over $\$ 12$ million per in 2014, and over \$14 million in 2013 (Shell Foundation, 2014).

The Overseas Private Investment Corporation (OPIC) has become another large private sector investor in clean energy development and has pledged over $\$ 280$ million in clean energy and energy efficiency projects in India (The White House, n.d.).

It is important to note that the funding allocations in Table 5 are all suggestions based on estimations of each organization's spending relevant to clean energy initiatives, particularly in India. It will take reorganization of the budgets to make these allocations possible. It is also important to note that "Other" in the table refers to funding that could come from sources that do not deal with climate initiatives and clean energy. As mentioned previously, clean cookstove programs may be viewed as both climate change initiatives as well as public health initiatives. Clean energy development funding can make up a large portion of the funding needed to support a clean cookstove program, but likely not all of it. Thus, it is essential that funding come from public health grants and funding mechanisms, possibly in partnership with large organizations like the World Health Organization, which understands the need for clean cookstoves in India.

Table 5. Suggested Funding Allocation by Organization for New National Program.

\begin{tabular}{ll}
\hline Organization & $\begin{array}{l}\text { Suggested Funding Allocation } \\
\text { (in million USD) }\end{array}$ \\
\hline U.S.-India Partnership on Clean Energy & $\$ 500.0$ \\
The Shell Foundation & $\$ 15.0$ \\
Overseas Private Investment Corporation & $\$ 100.0$ \\
Government of India & $\$ 500.0$ \\
Other (Public Health Funding) & $\$ 119.5$ \\
Total & $\mathbf{\$ 1 , 2 3 4 . 5}$ \\
\hline
\end{tabular}




\section{Concluding Remarks}

As stated by the Climate and Clean Air Coalition Secretariat, "One of the fastest and most cost-effective ways for targeting the gradual and often imperceptible changes wrought by climate may be by tackling the visible: smog and haze over our kitchens and landscapes" (Chan, Brende, \& Mohammed, 2016, p. 2). The need is clear for India to seriously address this enormous public health risk and limit black carbon emissions and preserve their forests.

The key to creating a new national clean cookstove program that is well supported is by making it a national priority from both a climate change standpoint and a public health initiative. By building upon existing partnerships and the suggestion of the program being led by two Indian ministries, there will be checks and balances to ensure each partner fulfills their contributions. It is important to note that this program should be implemented over the course of five years. While the funding for such a program appears enormous, each funder would have several years to provide funds.

As demonstrated in this analysis, a new national clean cookstove initiative qualifies within the realm of both a climate mitigation and adaptation action, and has already been highlighted in many important national initiatives, including India's INDC for the Paris Agreement. With the right support and partnerships, this initiative is possible and could have incredible climate, health, and economic benefits, as well as inspire other countries to take similar action. 


\section{BIBLIOGRAPHY}

Adler, T. (2010). Better burning, better breathing: improving health with cleaner cook stoves. Environmental Health Perspectives, 118, A 124-129. doi:10.1289/ehp.118a124

Ali, A., Riaz, S., \& Iqbal, S. (2014). Deforestation And Its Impacts On Climate Change An Overview Of Pakistan. Papers on Global Change IGBP, 21(1), 51-60. doi:10.1515/igbp-2015-0003

Barnes, D. F., Kumar, P., \& Openshaw, K. (2012). Cleaner hearths , better homes: new stoves for India and the developing world. Retrieved from http://www.esmap.org/sites/esmap.org/files/Cleaner Hearths, Better Homes_Book_Small.pdf

Blunck, M. (2013). Ingredients for Sustainable Cookstove Interventions. New Delhi.

Brooks, N., Bhojvaid, V., Jeuland, M. ., Lewis, J. ., Patange, O., \& Pattanayak, S. . (2015). How Much do Alternative Cookstoves Reduce Biomass Fuel Use? Evidence from North India. Resource and Energy Economics, 43, 153-171. doi:10.1016/j.reseneeco.2015.12.001

Chan, M., Brende, B., \& Mohammed, A. (2016, May 17). Air Pollution and Impacts on Women's and Children's Health and Climate Change. Climate and Clean Air Coalition. Retrieved from http://www.ccacoalition.org/en/news/air-pollution-andimpacts-women?s-and-children?s-health-and-climate-change

Chandrashekhar, V. (2015, April). Up in smoke. The Caravan. Retrieved from http://www.caravanmagazine.in/reportage/smoke-India-perfect-cookstove? page $=0,3$

Ge, M., Friedrich, J., \& Damassa, T. (2014). 6 Graphs Explain the World's Top 10 Emitters. World Resources Institute Blog. Retrieved from http://www.wri.org/blog/2014/11/6-graphs-explain-world's-top-10-emitters

Global Alliance for Clean Cookstoves. (2012). Uganda Market Assessment.

Global Alliance for Clean Cookstoves. (2013). India Cookstoves and Fuels Market 
Assessment. Washington, DC.

Global Alliance for Clean Cookstoves. (2015). Beyond Distribution : Ensuring and Evaluating the Adoption of Clean Cooking and Its Benefits. Lima, Peru.

Global Alliance for Clean Cookstoves. (2016a). India. Retrieved May 28, 2016, from $\mathrm{http}: / /$ cleancookstoves.org/country-profiles/focus-countries/5-india.html

Global Alliance for Clean Cookstoves. (2016b). Our Mission. Retrieved May 28, 2016, from http://cleancookstoves.org/about/our-mission/

Global Alliance for Clean Cookstoves. (2016c). Stoves. Retrieved May 28, 2016, from http://cleancookstoves.org/technology-and-fuels/stoves/

Government of India. (2012). India Second National Communication to the United Nations Framework Convention on Climate Change. Retrieved from http://unfccc.int/resource/docs/natc/indnc2.pdf

Government of India. (2016a). INDIA 'S INTENDED NATIONALLY DETERMINED CONTRIBUTION.

Government of India. (2016b). Outcome Budget 2015-16 Ministry of New and Renewable Energy.

Lewis, J. J., Bhojvaid, V., Brooks, N., Das, I., Jeuland, M. A., Patange, O., \& Pattanayak, S. K. (2015). Piloting Improved Cookstoves in India. Journal of Health Communication, 20(sup1), 28-42. doi:10.1080/10810730.2014.994243

Malla, S., \& Timilsina, G. R. (2014). Household Cooking Fuel Choice and Adoption of Improved Cookstoves in Developing Countries A Review. Policy Research Working Paper, World Bank, Washington D.C., (June), 52.

Ministry of Environment and Forests. (2015). National Mission for a Green India. New Delhi. 
Ministry of New and Renewable Energy. (2013). Implementation of Unnat Chulha Abhiyan (UCA) Programme during the year 2013- 2014 and balance period of the 12th Plan, 13(3).

Ministry of New and Renewable Energy. (2014). National Biomass Cookstoves Programme. Retrieved May 20, 2016, from http://mnre.gov.in/schemes/decentralized-systems/national-biomass-cookstovesinitiative

Preedy, V. R., \& Watson, R. R. (Eds.). (2010). Handbook of Disease Burdens and Quality of Life Measures (p. 4184). New York, NY: Springer New York. doi:10.1007/978-0-387-78665-0_5444

Ruiz-Mercado, I., Masera, O., Zamora, H., \& Smith, K. R. (2011). Adoption and sustained use of improved cookstoves. Energy Policy, 39(12), 7557-7566. doi:10.1016/j.enpol.2011.03.028

Shell Foundation. (2014). Report of the trustees and financial statements for the year ended 31 December 2014. Retrieved from http://www.shellfoundation.org/CMSPages/GetFile.aspx?guid=9810c6f5-0a0b4b39-b714-347fcc4e5367

Sloss, L. (2012). Black carbon emissions in India. IAE Clean Coal Centre.

Smith, K. R. (2013). Global and Indian Burdens of Disease from Household Air Pollution : the GBD 2010 Study Expert Group.

Steer, A. (2016). The Paris Climate Promise: A Good Deal for America. Washington, DC.

The Department of Commerce, Department of Energy, Department of State, Corporation, E.-I. B. of the U. S. O. P. I., Development, U.S. Agency for International Development, \& U.S. Trade and Development Agency. (2015). U . S . -India Partnership to Advance Clean Energy ( PACE ).

The White House. (n.d.). Fact Sheet on U.S.-India Partnership on Clean Energy, Energy Security, and Climate Change. doi:10.1017/CBO9781107415324.004 
The World Bank. (2016). Access to electricity (\% of population). The World Bank, 1-11. Retrieved from http://data.worldbank.org/indicator/EG.ELC.ACCS.ZS

U.S. Agency for International Development. (2016). ENERGY , FORESTRY , AND GLOBAL CLIMATE CHANGE. Retrieved May 20, 2016, from https://www.usaid.gov/india/energy-environment-and-global-climate-change

United Nations Framework Convention on Climate Change. (2014). First Steps to a Safer Future: Introducing the United Nations Framework Convention on Climate Change. Retrieved May 28, 2016, from http://unfccc.int/essential_background/convention/items/6036.php

United Nations Framework Convention on Climate Change. (2016). Climate Get the Big Picture. Retrieved May 28, 2016, from http://bigpicture.unfccc.int/\#content-theparis-agreemen

Venkataraman, C., Sagar, A. D., Habib, G., Lam, N., \& Smith, K. R. (2010). The Indian National Initiative for Advanced Biomass Cookstoves: The benefits of clean combustion. Energy for Sustainable Development, 14(2), 63-72. doi:10.1016/j.esd.2010.04.005

Waskow, D., \& Bapna, M. (2015, January 21). As Obama and Modi Meet , 4 Opportunities for US-India Action on Clean Energy and Climate. World Resources Institute. Washington, DC.

Westphal, M. I., Canfin, P., Ballesteros, A., \& Morgan, J. (2015). Getting to $\$ 100$ billion: Climate finance scenarios and projections to 2020, (May), 1-20. 